\title{
HUBUNGAN BOBOT BADAN DAN PRODUKSI SUSU KAMMBIG PERANAKAN ETAWA (PE
}

\author{
Nibras K. Laya , Fahrul Ilham, Suharyanto Suyono \\ Animal husbandry departmen, Agriculture Faculty, Gorontalo State University \\ nibraslaya@ung.ac.id
}

\begin{abstract}
The aim of this study was to determine how much the relationship of body weight and goat milk production of PE. This research was carried out at the Regional Technical Implementation Unit (UPTD) of Wonggahu Livestock Development in April to May 2017. The variables observed were body weight and goat milk production of PE. Number of PE goats studied by 30 tail. The data obtained were analyzed using simple regression by and simple correlation analysis by. The results showed that the average body weight of goat PE was 41.2 $\mathrm{kg} / \mathrm{head} /$ day with milk production of 0.339 liter/head/day. The relationship of body weight and goat milk production of PE is strong with a correlation value of 0.691 with a coefficient of determination of 0.477 . Contribution of body weight to goat milk milk production of $47.7 \%$ and the remaining $52.3 \%$ influenced by other factors not examined. the regression equation of body weight with goat milk production of $\mathrm{PE}$ is $\mathrm{Y}=0,316+0,001 \mathrm{X}+\mathrm{e}$.
\end{abstract}

Keywords: Body Weight, Milk Water, Etawa Peranakan Goat (PE)

\section{PENDAHULUAN}

Ternak Perah adalah ternak yang dapat memproduksi susu melebihi kebutuhan anaknya dan dapat mempertahankan produksi susu sampai jangka waktu tertentu walaupun anaknya sudah disapih atau lepas susu. Jenis ternak Perah yang ada antara lain sapi Perah, kambing PE dan kerbau Perah. Ternak Perah diperlihara khusus untuk diproduksi susunya.

Pada dasarnya jenis kambing merupakan ternak dwiguna, artinya kambing dipelihara untuk menghasilkan susu dan daging. Diantara kambingkambing Perah, kambing PE termasuk tipe kambing Perah unggul, karena memiliki kemampuan memproduksi susu sebanyak 1,5 - 3 liter/hari. Dengan kemampuan produksi susu tersebut maka kambing PE cukup signifikan untuk dikembangkan sebagai ternak penghasil susu yang sangat potensial.
Produksi susu nasional belum mampu memenuhi seluruh kebutuhan konsumsi nasional. Dengan demikian impor susu dan produk susu tetap dilaksanakan. produksi susu, konsumsi susu dan impor susu akan terus meningkat, sehingga perlu peningkatan populasi dan efisiensi produksi susu pada ternak Perah. pemeliharaan kambing Perah merupakan salah satu upaya untuk peningkatan produksi susu.

Produksi susu dipengaruhi oleh faktor umur, lingkungan, pemberian pakan dan salah satunya bobot badan.

Bangsa kambing Perah yang didatangkan dari daerah beriklim sejuk rentan sekali terhadap cekaman panas. Tatalaksana pemeliharaan, pemberian pakan harus diperhatikan guna menekan sekecil pengaruh cekaman panas tersebut. Rendahnya bobot tubuh ternak Perah di Indonesia mungkin merupakan hasil akhir adaptasi terhadap lingkungan yang lembab dan tropis. 
Bobot tubuh ternak Perah berkolerasi positif dengan produksi susu. Ternak yang lambat dewasa dengan kurva pertumbuhan mendatar cenderung menghasilkan susu lebih banyak dibandingkan ternak yang tumbuh lebih cepat. Ternak Perah mempunyai bobot badan lebih rendah daripada ternak pedaging.

Produksi susu yang tinggi pada induk sedang laktasi selama bulan pertama berpengaruh terhadap bobot tubuh induk dan dapat mengakibatkan penurunan bobot tubuh selama bulan pertama setelah melahirkan (berkisar antara 15-16 \%). penurunan bobot tubuh ini disebabkan oleh beberapa faktor misalnya nutrisi induk selama sebelum dan sesudah beranak, musim beranak dan cara pemeliharaan. Akan tetapi faktor cekamam laktasi belum jelas. Kehilangan bobot tubuh selama laktasi sepenuhnya normal sehingga diperlukan energi tersedia yang tinggi untuk produksi susu tanpa menyebabkan beban berlebihan pada sisitem pencernaan. perlunya tata laksana pemberian pakan yang baik pada saat bunting dan laktasi agar tersedia cadangan yang cukup pada waktu beranak dan mencegah kehilangan bobot tubuh yang berlebihan selama laktasi.

Sekresi susu akan cepat naik ketika kambing sesudah beranak dan akan lebih banyak pada kambing Perah yang beranak lebih dari satu anak. Jumlah susu yang disekresi per hari akan naik untuk 2-4 minggu sesudah beranak dan banyak faktor yang memPengaruhi lama waktu yang diperlukan untuk memperoleh produksi maksimum. peningkatan produksi susu yang tidak diimbangi oleh peningkatan konsumsi pakan pada awal laktasi mengakibatkan ternak akan memobilisasi cadangan nutrisi tubuhnya sehingga terjadi penyusutan bobot tubuh selama laktasi untuk produksi susu.
Peternakan di Provinsi gorontalo merupakan salah satu sektor utama mata pencarian masyarakat disamping sektor pertanian perkebunan. Tarnak perah khususnya kambing perah belum banyak dikembangkan oleh masyarakat, hal ini disebabkan tingkat pengetahuan masyarakat yang masih minim terkait mengenai ternak tersebut dan kurangnya data penelitian terkait kambing perah di provinsi gorontalo, baik terkait produksi, bobot badan, produksi susu, dan potensi pengembangan peternakan kambing perah.

Populasi ternak kambing PE di Gorontalo pada tahun 2017, sebanyak 6.798 ekor tersebar di seputaran Kota Gorontalo

\section{METODE PENELITIAN}

Penelitian dilaksanakan pada bulan April - Mei 2017 di Unit Pelaksana Teknis Daerah (UPTD) Pengembangan Ternak Wonggahu.

Alat yang digunakan meliputi timbangan digital dengan kapsitas maksimal 2 ton dengan ketelitian $0,5 \mathrm{~kg}$ dan berat $25 \mathrm{~kg}$ dan literan dengan kapasitas $2000 \mathrm{ml}$. Bahan yang digunakan adalah air susu dan 30 ekor kambing PE. Variabel yang diamati meliputi bobot badan dan produksi susu kambing PE.

Metode pengumpulan data dilakukan dengan penimbangan dan pemerahan susu kambing PE yang berjumlah 30 ekor dan dilakukan pengulangan sebanyak tujuh kali (tujuh hari).

Data diolah dengan menggunakan analisis regresi sederhana dan korelasi sederhana.

1. Analisis Regresi Sederhana

$$
Y=a+b X+e
$$

keterangan $: \mathrm{Y}=$ Produksi Susu

$\mathrm{X}=$ Bobot Badan

a $=$ Konstanta

$\mathrm{b}=$ Koefisien Regresi

e $=$ Batas Toleransi kesalahan

2. Analisis Korelasi

$$
\mathrm{r}=\frac{\mathrm{n}\left(\sum \mathrm{XY}\right)-\left(\sum \mathrm{X}\right)\left(\sum \mathrm{Y}\right)}{\sqrt{\mathrm{n}\left(\sum \mathrm{X}^{2}\right)-\left(\sum \mathrm{X}\right)^{2} \cdot \mathrm{n}\left(\mathrm{Y}^{2}\right)-\left(\sum \mathrm{Y}\right)^{2}}}
$$




\section{HASIL DAN PEMBAHASAN}

\section{Bobot Badan Kambing Peranakan Etawa (PE)}

Berdasarkan hasil penelitian bobot badan kambing peranakan etawa (PE) dengan tujuh kali ulangan didapatkan rata-rata 41,2 $\mathrm{kg} /$ ekor/hari. Hal ini lebih rendah dengan pernyataan dari Lembah Gogoniti Farm (2008), yang menyatakan bahwa performa kambing PE yaitu badan besar dengan bobot badan hidup jantan adalah antara 65$90 \mathrm{~kg}$, untuk betina $45-70 \mathrm{~kg}$.

Faktor penyebab bobot badan kambing PE lebih rendah di lokasi penelitian (UPTD) wonggahu, karena faktor tata laksana waktu pemberian pakan yang kurang tepat . pemberikan pakan di lakukan pada jam 09.00-16.00 pada kambing PE .hal ini sejalan dengan pernyataan (Rudiah, 2011). Untuk meningkatkan bobot badan pada ternak kambing, pemberian pakannya sebaiknya dimulai pada pagi hari yaitu mulai pukul 08.00 - 14.00. Hal ini dilakukan karena pada pagi hari ternak mendapat kesempatan yang banyak pula untuk mengunyah makanan tersebut.

Semakin banyak waktu yang diberikan kepada ternak kambing untuk mengkonsumsi pakan, maka akan menghasilkan bobot badan yang lebih optimal. Sebaliknya, pemberian pakan pada ternak kambing yang dilakukan pukul 14.00 - 17.30, ternak tidak memiliki kesempatan yang lebih banyak untuk mengkonsumsi pakandan tidak dapat menguyah makanannya dengan baik, sehingga akan mengh asilkan bobot badan yang kurang optimal.

Bobot badan kambing peranakan etawa akan berpengaruh terhadap produksi susu kambing peranakan etawa (PE) itu sendiri. Hal ini sejalan dengan pernyataan Morand-Fehr (1991) bahwa kambing perah dengan bobot badan yang lebih besar akan memiliki tingkat produksi susu yang lebih tinggi dibandingkan dengan kambing dengan bobot badan rendah, sehingga bobot badan secara tidak langsung memiliki pengaruh terhadap produksi susu yang dihasilkan, hal ini karena bobot badan menentukan kematangan dan kesiapan selsel kelenjar ambing untuk memproduksi susu dan menentukan ragam produksi susu di awal laktasi. Lebih lanjut menurut Ramdan (2007) menyatakan bahwa lingkar dada berkorelasi positif terhadap bobot badan, sehingga semakin besar ambing yang diakibatkan oleh perkembangan sel sekretori akan menyebabkan bertambahnya bobot badan pada kambing sehingga meningkatkan produksi susu.

\section{Produksi Susu Kambing Peranakan Etawa} (PE)

Berdasarkan hasil penelitian produksi susu kambing peranakan etawa (PE) dengan tujuh kali ulangan didapatkan rata-rata sebesar 0,339 liter/ekor/hari. Hal ini lebih rendah dari pernyataan Sudono dan Abulgani (2002) yang menyatakan bahwa produksi susu kambing PE cukup rendah, yaitu berkisar 0,5-0,9 liter/ekor/hari. Hal serupa disampaikan Sodiq dan Abidin, (2009) yang menyatakan bahwa produksi susu yang dihasilkan kambing PE adalah 0,452-2,2 liter/ekor/hari dengan masa laktasi cukup beragam yaitu antara 92-256 hari dengan rataan 156 hari.

Produksi susu kambing peranakan etawa di Unit Pelaksana Teknis Daerah (UPTD) masih rendah karena dipengaruhi oleh beberapa faktor: Kondisi iklim di Unit Pelaksana Teknis Daerah (UPTD) wonggahu adalah termasuk daerah yang iklim tropis, Sehingga produktivitas air susu kambing peranakan etawa (PE) lebih rendah. Iklim didaerah tropis mempunyai aspek terhadap kemampuan berproduksi susu. Payne (1962) mengutarakan bahwa salah satu aspek langsung dari iklim tropis terhadap produksi ternak perah pada umumnya adalah ketidakmampuan ternak mencukupi kebutuhan untuk berproduksi, sebagai akibat dari menurunnya napsu makan dan rendahnya kualitas hijauan. 
Pemerahan susu yang dilakukan oleh lebih dari satu orang (tidak menetap) sehingga akan mengakibatkan kambing setres, maka produksi susu juga akan menurun.

Sanitasi kandang yang kurang baik. Kebersihan kandang yang kurang maka akan berpengaruh juga terhadap produksi susu yang dihasilkan.

Hal serupa seperti yang dikemukakan oleh Phalepi (2004), yang menyatakan bahwa produksi susu dipengaruhi oleh mutu genetik, umur induk, ukuran dimensi ambing, bobot hidup, lama laktasi, tatalaksana yang diberlakukan terhadap ternak (perkandangan, iklim dan kesehatan), kondisi iklim setempat, daya adaptasi ternak dan aktivitas pemerahan.

Hubungan Bobot Badan dengan Produksi Susu

\section{Koefisien Korelasi (r)}

Pengaruh bobot badan terhadap produksi susu kambing peranakan etawa (PE) dapat diketahui dengan menggunakan analisis regresi sederhana dan korelasi sederhana. Hasil analisis regresi dan korelasi sederhana disajikan pada tabel diibawah ini.

\begin{tabular}{cccc}
\hline $\begin{array}{c}\text { Konstanta } \\
\text { (a) }\end{array}$ & $\begin{array}{c}\text { Beta } \\
\text { (b) }\end{array}$ & (r) & $\begin{array}{c}\text { Square } \\
\left(\mathrm{r}^{2}\right)\end{array}$ \\
\hline 0,316 & 0,0001 & 0,691 & 0,477 \\
\hline
\end{tabular}

Sumber : data olahan, 2017

Berdasarkan koefisien perhitungan korelasi linier sederhana seperti yang tertera pada tabel diatas diperoleh nilai koefisien korelasi (r) sebesar 0,691 dimana nilai ini bernilai positif dan mendekati 1 yang artinya bobot badan berpengaruh kuat dan positif terhadap produksi susu kambing peranakan etawa (PE). Hal ini seperti yang disampaikan Sugiyono (2007) tentang pedoman untuk memberikan interpretasi koefisien korelasi sebagai berikut :

0,00 - 0,199 Sangat Rendah, 0,20 - 0,399

Rendah, 0,40 - 0,599 Sedang, 0,60 - 0,799

Kuat, 0,80 - 1,000 Sangat Kuat

Koefisien korelasi (r) terbagi atas dua yaitu koefisien positif dan koefisien negatif dengan angka berkisar antara -1 hingga +1 , dimana mendekati +1 koefisien korelasi menunjukan adanya hubungan positif sedangkan koefisien korelasi yang mendekati -1 menunjukan hubungan yang negatif, jika koefisien mendekati 0 memberikan indikasi bahwa kedua variabel tidak memiliki hubungan.

\section{Koefisien Determinasi $\left(\mathbf{r}^{2}\right)$}

Menurut Saputra (2012) koefisien determinasi adalah untuk melihat berapa besar kontribusi atau sumbangan variabel independen $(X)$ terhadap variabel dependen (Y) dari analisis regresi.

Pada tabel . menunjukkan bahwa dari hasil analisis regresi sederhana dan korelasi sederhana diperoleh nilai koefisien korelasi (r) sebesar 0,691 dan nilai koefisien determinasi $\left(\mathrm{r}^{2}\right)$ sebesar 0,477. Hal ini menunjukkan bahwa persentase kontribusi dari bobot badan terhadap produksi susu kambing peranakan etawa sebesar 47,7\%, sedangkan sisanya 52,3\% dipengaruhi oleh faktor lain yang tidak diteliti.

Besarnya persentase kontribusi tersebut menunjukkan pengaruh bobot badan kambing peranakan etawa (PE) untuk kelangsungan produksi susu kambing peranakan etawa kuat. Sehingga keberadaan bobot badan akan menjadi perhatian yang serius bagi peternak kambing peranakan etawa (PE).

\section{Analisis Regresi Sederhana Antara Bobot Badan dengan Produksi Susu}

Berdasarkan hasil perhitungan analisis regresi sederhana pada lampiran 5. antara hubungan bobot badan dan produksi susu kambing peranakan etawa diperoleh persamaan regresi sebagai berikut :

$$
\begin{aligned}
& Y=a+b X+e \\
& Y=0,316+0,001 X+e
\end{aligned}
$$

Persamaan regresi diperoleh nilai konstanta a adalah sebesar 0,316, yang berarti apabila variabel bebas yaitu bobot badan tidak mengalami perubahan maka jumlah produksi susu kambing peranakan etawa (PE) sebesar 0,316 liter/ekor/hari. 
Variabel bebas bobot badan menunjukkan pengaruh secara positif terhadap produksi susu kambing peranakan etawa (PE). Artinya peningkatan bobot badan kambing peranakan etawa (PE) akan meningkatkan juga produksi susu kambing peranakan etawa (PE).

\section{KESIMPULAN}

Terdapat hubungan yang kuat antara bobot badan dengan produksi susu kambing PE dengan nilai korelasi sebesar 0,691 . Kontribusi bobot badan terhadap produksi susu kambing PE untuk kelangsungan produksi susu kambing peranakan dengan nilai koefisien korelasi mendekati +1 , mengikuti persamaan regresi bobot badan dengan produksi susu kambing PE adalah $\mathrm{Y}=0,316+0,001 \mathrm{X}+\mathrm{e}$

\section{DAFTAR PUSTAKA}

Farm, Lembah Gogoniti. 2008. Ciri-ciri Kambing PE (Peranakan Etawah). WWW.Lembahgogoniti.Com. 19 September 2010.

Morand-Fehr, P. 1991. Goat Nutrition. Pudoc Publisher, Wageningen, The Netherlands, EAAP Publication No. 46, pp. 308.

Payne, W.J .A. 1962 Cimateand nutrisi hewan dalam daerah tropis. Span. 5: 118.
Phalepi, M. A. 2004. Performa kambing Peranakan Etawah (studi kasus di peternak Pusat Pelatihan Pertanian dan Swadaya Pedesaan Citarasa). Skripsi. Fakultas Peternakan. Institut Pertanian Bogor, Bogor.

Ramdan R. 2007. Fenotipe Domba Lokal di Unit Pendidikan, Penelitian dan Peternakan Jonggol. Fakultas Peternakan, Institut Pertanian Bogor. Bogor. (Skripsi Sarjana Peternakan).

Rudiah. 2011. Respon Kambing Kacang Jantan Terhadap Waktu Pemberian Pakan. Balai Penelitian Ternak. Bogor. www.jurnal.untad.ac.id.

Saputra, S. 2012. Metode Penelitian. Penerbit PT Refika Aditama. Bandung.

Sodiq, A. \& Z. Abidin. 2009. Meningkatkan Produksi Susu Kambing Peranakan Etawah. Cetakan Kedua. Agromedia Pustaka, Jakarta.

Sudono, A \& I. K. Abdulgani. 2002. Budidaya Aneka Ternak Perah. Diktat. Jurusan Ilmu Produksi Ternak. Fakultas Peternakan. Institut Pertanian Bogor, Bogor.

Sugiyono. 2007. Statistik Non Parametrik untuk penelitian. Penerbit CV Alfabeta. Bandung. 